\title{
MALE GENITALIA OF SOME NEPALESE SPECIES ONTHOPHAGUS LATREILLE (COLEOPTERA: SCARABAEIDAE)
}

\author{
S.P. Mahato
}

\section{ABSTRACT}

The present paper deals with the studies of male genitalia of Onthophagus Latreille, the common dung beetle of Nepal. The male genitalia are described and illustrated for 9 species of Onthophagus Latreille -O. pactolus (F.), O. aenescens (Wied.), O. ramosellus Bates, 0. sternalis Arrow, O. catta (F.), O. bonasus (F.), O. rectecornutus Lansb., O. atropolitus d'Orb., $O$. sagittarius F. of Nepal. The male genitalia of these species were found to be consisting of phallobase, parameres, aedeagus and endophallus similar to those of the other genera of Coprinae and primitive in their main features.

Key words : dung beetles, Dhanusha district, coprinae, phallobase, parameres, aedeagus, endophallus

\section{INTRODUCTION}

Genus Onthophagus Latreille is a predominent genus of the subfamily Coprinae, vastly outnumbering other genera of dung beetles in the most of the parts of the world. The name Onthophagus was first proposed by Latreille in 1802. Later on Arrow (1931) placed it in the subfamily Coprinae. These beetles are small, smooth with a compact body. These are easily recognised by the absence of scutellum, elytra with one lateral carina, pronotum without a strong basal groove; and four posterior tarsi not broadly dilated.

Male genitalia are one of the most important structures and are of great taxonomic impotance due to their constant nature of structure. So, the modern taxonomy of dung beetles is mainly based on male genitalia. Arrow (1931) completely ignored the taxonomic value of genitalia on the Coprinae beetles.

In India, Singh et al. (1983) studied the male genitalia of few species of Heliocopris Burm. Sewak studied the male genitalia of few species of Copris Geoffroy in 1984, those of few species of Onitis F. and Catharsius Hope in 1985, few species of Onthophagus Latr. in 1986, and few species of Gymnopleurus Illig. and Oniticellus Serv. in 1988. They provided simple and reliable keys for the identification of male dung beetles.

No studies so far has been carried out in male genitalia of dung beetles of Nepal. Therefore, the present study was carried out to provide new information for future taxonomic studies.

\section{MATERIALS AND METHODS}

Specimens of Onthophagus pactolus (Fabricius), O. aenescens (Wiedemann), O. ramosellus Bates, O. sternalis Arrow, O. catta (Fabricius), O. bonasus (Fabricius), O. rectecornutus Lansberge, $O$. atropolitus Orbigny and $O$. sagittarius Fabricius were collected from different forests, grass lands, rural and urban localities of Dhanusha district, Nepal from dung of the herbivorous animals primarily of cows and buffaloes by hand picking. Light trap and pitfall trap were also 
used for collection. Collected specimens were killed in the killing bottle in ethyl-acetate contained container. Specimens were preserved in both dry condition and in $70 \%$ alcohol.

Both preserved and freshly killed specimens were used to study the male genitalia. The dry preserved specimens were, however, relaxed in boiling water for 20 minutes and their abdomens were treated with potassium hydroxide $(\mathrm{KOH})$ at $10 \%$ for two days to dissolve the soft tissues in and around the membranous and sclerotised structure of genitalia. Abdomens were dissected under stereo-binocular microscope to expose the genitalia which were then taken out with the help of forceps and mounted in Canada balsam after dehydration process (Singh et al. 1983, Sewak 1984, 1985, 1986, 1988).

Photographs of male genitalia were taken by German microphotographic binocular microscope and were developed in the digital colour laboratory.

\section{RESULTS AND DISCUSSION}

Male genitalia are the modifications of posterior abdominal segments. Hence they consist of so-called "Phallic organs" (Snodgrass 1935). The 9th abdominal segment is greatly modified into the genital chamber in which the genitalia are suspended when at rest. The male genitalia of dung beetles consist of various sclerotized and membranous parts arranged around the terminal portion of the ejaculatory duct.

The ring shaped phallobase and tubular aedeagus of male genitalia of all the recorded species in the present study showed a closer resemblance with each other while the structures of parameres and endophallus are greatly different at species level.

Onthophagus pactolus (F.) (Fig. 1): Parameres are rectangular in shape. Endophallus is broad and rectangular.

Onthophagus aenescens (Wied.) (Fig. 2): Parameres are apically pointed, spine-like and curved inward forming a forcep-like structure. Endophallus is broadened apically and narrow proximally.

Onthophagus ramosellus Bates (Fig. 3): Parameres are broad apically and pointed proximally. Inner margin is furnished with sensory bristles. Endophallus is trilobed.

Onthophagus sternalis Arrow (Fig. 4): Parameres are broad and rounded apically. Endophallus is rectangular in shape.

Onthophagus catta (F.) (Fig. 5): Parameres are broad and rounded apically and are furnished with sensory bristles on inner margin. The dorsal surface of parameres has a conical sclerotized strcuture at the middle. Endophallus is an elongated and bilobed structure; the right lobe is broad and segmented apically and narrow proximally while left lobe is tubular.

Onthophagus bonasus (F.) (Fig. 6): Parameres are broad and rounded apically and are furnished with sensory bristles on inner margin. The dorsal surface of parameres has two segmented glandular sclerotized structure at the middle. Endophallus is bilobed; right lobe is broad and rounded apically while it is narrow proximally, the left lobe is tubular.

Onthophagus rectecornutus Lansb. (Fig. 7): Parameres are rectangular in shape and the 
lower margin is furnished with sensory bristles. The dorsal surface of the paramere has a clavate sclerotized structure at the middle. Endophallus is bilobed apically and narow proximally.

Onthophagus atropolitus d' Orb (Fig. 8): Parameres are broad and rounded apically. Endophallus is hammer - shaped.

Onthophagus sagittarius F. (Fig. 9): Parameres are conical shaped. Endophallus is flattened and rectangular in shape with two finger-like processes at the proximal end.

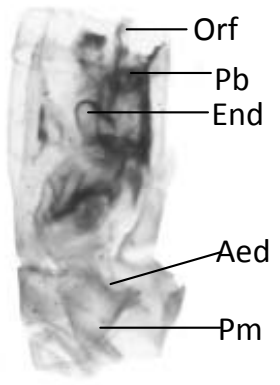

Fig. 1. Male Genitalia of Onthophagus pactolus F. (Length $1.5 \mathrm{~mm}$ )

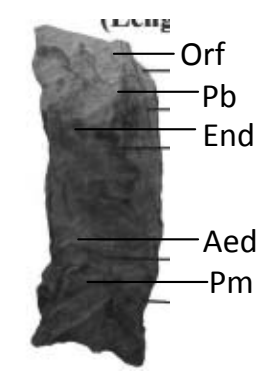

Fig. 4. Male genitalia of Onthophagus sternalis Arrow

(Length $1.5 \mathrm{~mm}$ )
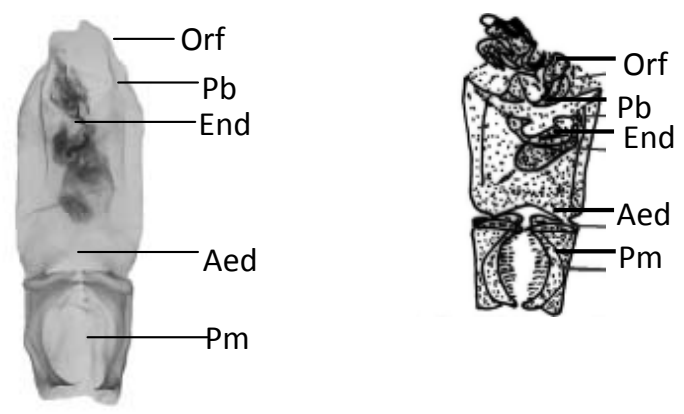

Fig. 2. Male genitalia of Onthophagus aenescens Wied

Fig. 3. Male genitalia of Onthophagus ramosellus Bates (Length $1 \mathrm{~mm}$ )

(Length $1.5 \mathrm{~mm}$ )

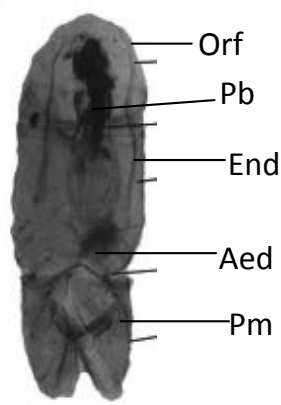

Fig. 5. Male genitalia of Onthophagus catta F.

(Length $2 \mathrm{~mm}$ )
(Source: Sewak 1986)

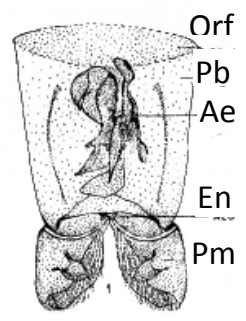

Fig. 6. Male genitalia of Onthophagus bonasus F. (Length $1.5 \mathrm{~mm}$ ) (Source: Sewak 1986) 


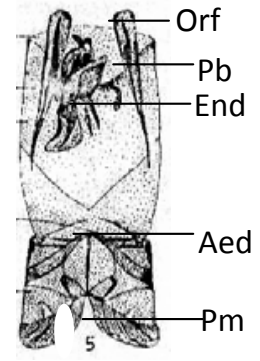

Fig. 7. Male genitalia of Onthophagus rectecornutus Lansb. (Length $1.5 \mathrm{~mm}$ ) (Source: Sewak 1986)

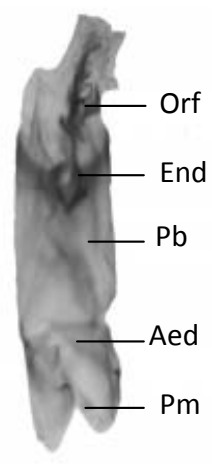

Fig. 8. Male genitalia of Onthophagus atropolitus d' Orb.

(Length $3 \mathrm{~mm}$ )

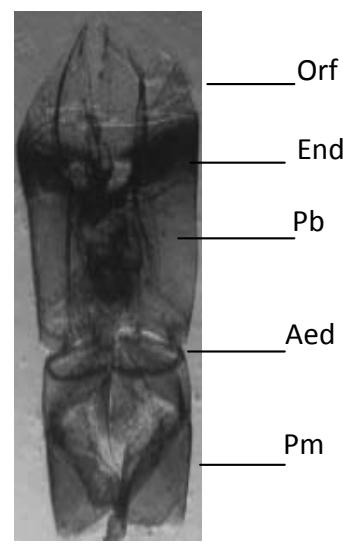

Fig. 9. Male genitalia of Onthophagus sagittarius F.

Aed: Aedeagus, End: Endophallus, Orf: Orifice, Pb: Phallobase, Pm: Parameres

The male genitalia of Onthophagus Latr. are primitive in their main features. The ring shaped structure of phallobase and tubular aedeagus show resemblance to those of the other genera of Coprinae, whereas the structure of parameres and endophallus is greatly different at both generic and species level.

Parameres are broad and rounded apically with sensory bristles on inner margin in $O$. ramosellus Bates, O. sternalis Arrow, O. Catta (F.), O. bonasus (F.) and O. atropolitus d' Orb; rectangular in $O$. pactolus (F.) and O. rectecornutus Lansb.; and conical in $O$. sagittarius $F$. Endophallus is rectangular in O. pactolus (F.), O. sternalis Arrow, and O. sagittarius F.; bilobed in O. catta (F.) O. bonasus (F.), O. rectecornutus Lansb.; trilobed in O. ramosellus Bates; and hammershaped in $O$. atropolitus d'Orb.

Thus the evidence of male genitalia of Onthophagus Latr. confirms its independent status in the family Scarabaeidae.

\section{ACKNOWLEDGEMENTS}

Author is grateful to Prof. Dr. V.K. Thapa (Retd.) former Head, Central Department of Zoology, Tribhuvan University, Kirtipur for his precious suggestions and for providing laboratory facilities.

\section{REFERENCES}

Arrow, G.J.,1931. The Fauna of British India including Ceylon and Burma. Coleoptera, Lamellicornia, III. Taylor and Francis, London, pp 1-428.

Sewak, R.,1984. Male genitalia of some Indian species of Copris Geoffroy (Coleoptera: Scarabaeidae) and its taxonomic importance. Oikoassay, 1(1-2):20-23. 
Sewak, R.,1985. Male genitalia of some Indian species of Onitis Fabricius (Coleoptera: Scarabaeidae). Oikoassay, 2(1): 18-19.

Sewak, R.,1985. Male genitalia of some species of Catharsius Hope (Coleoptera: Scarabaeidae) and its taxonomic importance. J. Anim. Morphol. Physiol., 33(1-2): 269-271.

Sewak, R.,1986. Male genitalia of Indian Onthophagus Latr. (Coleoptera: Scarabaeidae) and its taxonomic importance. J. Anim. Morphol. Physiol., 33(1-2): 135-140.

Sewak, R.,1988. Male genitalia of Indian Gymnopleurus Illiger (Coleoptera: Scarabaeidae) and its taxonomic importance. Oikoassay. 5(2): 43-45.

Sewak, R.,1988. Male genitalia of Indian Oniticellus Serveille (Coleoptera: Scarabaeidae) and its taxonomic importance. J. Anim. Morphol. Physiol., 35(2): 165-168.

Singh, S., R. Sewak and K.S. Rana,1983. Male genitalia of some Indian species of Heliocopris Burm. (Coleoptera: Scarabaeidae). J. Agric. Sci. Res., 25: 67-72.

Snodgrass, R.E.,1935. Principles of insect morphology. MC Grow Hill Book Co. New York Cit. IX,$+ 677 \mathrm{p}$.

\section{AUTHOR'S ADDRESS \\ Shyam Prasad Mahato}

Department of Zoology

R.R.M. Campus, Tribhuvan University, Janakpur, Nepal 